\title{
The Antecedents and Outcomes of Attachment and Sponsor Image Within Charity Sport Events
}

\author{
Kevin Filo, Daniel Funk, and Danny O'Brien \\ Griffith University
}

\begin{abstract}
Filo is with the Centre for Tourism, Sport and Service Innovation, Griffith University, Gold Coast, Queensland, Australia. Funk is with the Griffith Business School, Griffith University, Gold Coast, Queensland, Australia. O’Brien is with the Dept. of Tourism, Leisure, Hotel, and Sport Management, Griffith University, Gold Coast, Queensland, Australia.
\end{abstract}

Sport events benefiting a charitable cause have emerged as meaningful experiences for participants. These charity sport events may allow event sponsors to shape perceptions of corporate image among event participants. Using the Psychological Continuum Model (PCM) as the theoretical framework, the factors that contribute to participants' perceptions of event sponsors are examined. The influence of this image of event sponsors on behavioral outcomes among participants is also investigated. A post-event questionnaire was administered to participants in a sport event $(N=672)$ to investigate the relationships among motives, sponsor image, event attachment, purchase intent, and future participation intent. Results reveal that recreation and charity motives contribute to event attachment, while charity motives and event attachment contribute to sponsor image. Significantly, sponsor image and attachment contribute to purchase intent for event sponsors' products. Finally, sponsor image does not influence future participation intent, while event attachment does. The results illustrate the discrete roles that sponsor image and attachment play in sport consumption activities. Suggestions are made for the strategic selection and marketing of events by potential sponsors to most effectively leverage event sponsorship opportunities. 
Sport events benefiting a charitable cause have a large participant base from which to draw. In 2005, over 260 million Americans over the age of seven participated in sport more than once (U.S. Census Bureau, 2007). While sport participation continues to represent a prominent aspect of leisure and recreation, there has also been a pronounced shift toward support of charitable causes for both individual consumers and corporations (King, 2001). Consumer priority has shifted toward heightened ethical, social, and spiritual sensitivity, while corporate executives have recognized consumers' desire to align with products that provide meaning (Ebenkamp \& Stark, 1999).

The established popularity of sport participation, along with this consumer shift toward social awareness, places an emphasis on sport event sponsors to align with events that elicit meaning for participants. This has the added bonus of assisting sponsoring organizations in shaping their corporate image (Gwinner \& Eaton, 1999). The current study examines the factors that contribute to perceptions of sponsor image along with participant attachment to sport events, as well as the influence of attachment and sponsor image on participant behavior.

The number of charitable organizations in the United States continues to rise. Between 1996 and 2004, the number of registered public charities increased 53\% from 535,888 to 822,817 (National Center for Charitable Statistics, 2004), reaching 904,313 in 2006 (National Center for Charitable Statistics, 2007). Increasingly, these charities are turning to sport participation as a means to raise funds (King, 2001). Beyond participant donations and fundraising, these charity sport events are bolstered by corporate support and sponsorship. Projections for 2008 had \$11.6 billion spent on the sponsorship of sport along with an additional \$754 million on festivals, fairs, and annual events (Cause Marketing Forum, 2008). The large participant base in place combined with the wide array of prospective charities to support, and the high dollar expenditures on sponsorship, bring forth a challenge to corporate sponsors to align with successful and meaningful events to maximize their return on investment.

The purpose of this research is twofold: first, the factors that contribute to event attachment and sponsor image in the sport event context are examined; second the influence of event attachment and sponsor image on sponsor product purchase intent and future event participation intent is explored. The 2007 3M Half Marathon and Relay serves as the research context as it allows individuals to participate in a sport event aligned with a corporate sponsor, while event proceeds benefit a charitable cause.

This manuscript is divided into three sections. First, the theoretical framework is introduced leading to a review of motives for event participation and sponsor image. Second, the research methods employed are described. Finally, the results are detailed along with implications, limitations, and directions for future research. 


\section{Literature Review}

\section{Theoretical Framework}

This research utilizes Funk and James’s (2001, 2006) Psychological Continuum Model (PCM) as the theoretical basis. The PCM is founded upon the notion that both individual and social situational factors work together in the development of recreation participation (Funk \& James, 2006). The PCM conceptualizes the variety of ways consumers relate to a sport object in terms of four stages along a vertical continuum: awareness, attraction, attachment, and allegiance. Each stage represents an upgraded level of psychological connection that the consumer feels toward the object (Funk \& James, 2001).

The PCM was selected for the current research because of its focus on the psychological relationship an individual forms with a sport object (Funk \& James, 2001). The framework is one of the few stage-based models that examine movement both up and down, which is relevant to event participation and attrition. The PCM was developed for application to all sport, and is considered theoretically sound for understanding both active and passive participation (Stewart, Smith, \& Nicholson, 2003).

In their evaluation of theoretical frameworks for examining active recreation participation, Beaton and Funk (2008) argue that the PCM is a sound choice to guide research on participation in physically active leisure. Six theoretical frameworks applicable for understanding the development of physically active leisure were compared. The authors suggest that the PCM provides an integrated foundation that can be used to improve the research-practice dynamic, while allowing for thorough testing of policies, programs, and interventions. The PCM can be used for both passive and active forms of recreation participation, and recent application in understanding decision making for active sport participation has proved instructive (Funk, Toohey, \& Bruun, 2007). The current research represents application of the PCM framework in the sport event context.

The PCM advances processes that operate within and among awareness, attraction, attachment, and allegiance outcomes. The awareness process occurs through socialization via friends and media leading to an individual obtaining the knowledge that a sport event will be occurring, or awareness outcomes. From there, the attraction process involves this knowledge that the sport event exists interacting with perceived hedonic motives, dispositional needs, and social situational factors that drive event participation. The interaction among these motives, needs, and factors evolves into individual preference for the event based on the event's ability to provide benefits and satisfy needs. Preference for the event along with the satisfaction of the 
needs and motives driving event participation are considered attraction outcomes.

The needs and motives satisfied through event participation can take on greater meaning for the participant, interacting with their self-concept, while aligning with core values, demonstrating the attachment process. The attachment process produces attachment outcomes, which include increased importance for the motives that drive participation, and for the event overall, as well as the event taking on emotional, symbolic, and functional meaning for the participant. Funk and James (2006) suggest that these attachment outcomes may form, grow stronger, and feedback into the attachment process, eventually leading to allegiance, or loyalty to the event. In this case, allegiance outcomes reflect the durability and overall impact of attachment outcomes (Funk \& James, 2006).

The current research focuses specifically on the attachment process. Event participants have already demonstrated awareness and attraction to the event through their registration and participation. However, these participants, particularly those in their first year of participation, may not demonstrate consistent commitment or allegiance to the event. Funk and James (2006) contend that the attachment process requires additional development, and this research responds to this suggestion through an examination of factors that may contribute to attachment.

\section{Attachment}

Attachment is considered a universal human experience that occurs throughout the lifecycle (Schultz, Kleine, \& Kernan, 1989), which provides an opportunity for bothself-expressionas wellasconnection to others (Wallendorf\&Arnould,1988). Funk and James (2006) define attachment in the sport context as an individual assigning emotional, symbolic, and functional meaning to a sport object. Attachment is conceived of as a dynamic process in which a sport object can be used by an individual to develop strong attitudes and self-expression (Funk \& James, 2006). An individual's relationship with a sport object has been found to provide a sense of attachment (Trail, Anderson, \& Fink, 2000) through a connection with various facets of that object (Robinson \& Trail, 2005). In the sport event context, an individual may feel attached to the event based on their connection to, and relationship with, aspects of the event such as the sport activity, the other participants, or the benefiting charity (e.g., Filo, Funk, \& O’Brien, 2008, 2009). Consequently, an individual may be driven to participate in a charity sport event based upon motives that reflect their connection with these sport and charity-oriented facets.

As outlined above, the PCM framework suggests the motives that drive event participation can interact with a participant's self-concept and values, taking on greater meaning and significance in the participant's life. This leads to the event taking on emotional, symbolic, and 
functional meaning. To further refine the attachment process in the sport event context, a better understanding of the motives satisfied through sport event participation is needed.

\section{Recreation Motivation}

Motivation is defined as, "an internal factor that arouses, directs, and integrates a person's behavior" (Iso-Ahola, 1982, p. 230). Prominent within the PCM framework is a discussion of core motives for sport and recreation participation. Research has uncovered a variety of motives that drive event participation based on a number of different frameworks including Maslow's hierarchy of needs (Getz, 1991; Maslow, 1954), Iso-Ahola’s escape-seeking model (Iso-Ahola, 1980, 1982; Mannell \& Iso-Ahola, 1987), and the premise of push-pull factors (Crompton, 1979; Crompton \& McKay, 1997; Zhang \& Lam, 1999).

The hierarchy of needs states that physiological needs must be satisfied before higher order social and personal needs (Maslow, 1954). Getz (1991) suggests that events and festivals can satisfy an individual's physical, social, and personal needs. In challenging the hierarchy of needs, Iso-Ahola $(1980,1982)$ believes there are two motivational forces for tourism: seeking and escaping. Leisure and recreation participation are means to satisfy these needs as they represent opportunities for self-determination, sense of competency or mastery, challenge, learning, exploration, relaxation, and social interaction (Mannell \& Iso-Ahola, 1987).

The concept of push-pull factors builds on this notion advancing push motives as the escaping motivational force and pull motives as the seeking motivational force (Crompton \& McKay, 1997). Push factors include motives such as escape, socialization, and knowledge seeking (Crompton, 1979; Zhang \& Lam, 1999). Most notably, Beard and Ragheb (1983) advanced four dimensions of leisure motivation: intellectual, social, escape, and competency motives; related to leisure needs.

Each of these four dimensions has been highlighted in the existing literature on motivation (Crompton, 1979; Crompton \& McKay, 1997; Mannell \& Iso-Ahola, 1987; Zhang \& Lam, 1999) and active sport participation (Frederick \& Ryan, 1993; Kavussanu \& Roberts, 1996; Kilpatrick, Hebert, \& Bartholomew, 2005; Koivula, 1999; Laverie, 1998).

These dimensions represent core factors that can drive event participation in general and are relevant to the sport event context in particular (Funk et al., 2007). However, additional consideration in the form of contextual motives related to the benefiting charity may also serve to fulfill needs within consumers and lead to participation (Funk \& James, 2004). With regard to these sport events, the charitable component represents one such aspect as factors related to charitable giving may serve as motivation contributing to event participation. 


\section{Charitable Giving Motivation}

Giving to charity is a complex decision driven by a variety of motives. Dawson (1988) examined consumer donations to medical research and suggested that reciprocity is an important motivating factor. Reciprocity has also been found to be a significant motivating factor for charitable donations among young professionals (Kottasz, 2004). Reciprocity involves an individual giving to charity because he or she has benefited from, or anticipates benefiting from, the charity's central activities (Dawson, 1988). Research has also suggested motives related to inherent needs of donors such as self-esteem and the need to help others (Amos, 1982; Hibbert \& Horne, 1996; Marx, 2000; Ritzenheim, 2000).

Within the sport management literature, motivation for donations to college athletic programs has received considerable attention (e.g., Stinson \& Howard, 2004, 2007, 2008). Athletic programs allow universities to strengthen relationships with alumni, and attract donations. Similarly, sport events allow charitable organizations to foster connections with stakeholders and constituents, as well as generate funds through donations. A number of the motives uncovered in the literature on donor motivation in college athletics are applicable to the charity sport event context.

In the athletic domain, a factor that significantly influences donations is the desire to improve and/or support an athletic program (Gladden, Mahony, \&Apostolopoulou, 2004; Staurowsky, Parkhouse, \& Sachs, 1996). This suggests that donors want to be affiliated with a successful institution and see the donation as a way to help the institution toward success. Athletic success has been found to have a pronounced influence on institutional giving (Stinson \& Howard, 2004, 2008), with athletic success representing a key element toward attracting new donors (Stinson \& Howard, 2007). Indeed, lesser known and unsuccessful charities are less likely to have donors or members who identify with their organization (Fisher \& Wakefield, 1998). The desire to improve the charity seems to be relevant as donors may view their donation as an opportunity to improve the charitable organization's standing. Factors related to charitable giving represent contextual motives that can be satisfied through participation in a sport event benefiting a charitable cause.

The core and contextual motives outlined above have been examined in the charity sport event context. Intellectual, social, and competency motives along with the motives of reciprocity, self-esteem, need to help others, and desire to improve the charity have been found to contribute to attraction to a charity sport event (Filo et al., 2008). The PCM framework suggests the motives and needs that foster attraction to an event can take on enhanced meaning, while interacting with the participant's self-concept and values, leading to the event taking on emotional, symbolic, and functional meaning (Funk \& James, 2006). Emotional, symbolic, and functional meaning 
represents attachment to the event.

Beyond the factors that contribute to participant attachment, the relevance of attachment to event sponsors requires further examination. Research suggests that positive consumer response to a sport event transfers to event sponsors (Crimmins \& Horn, 1996). The current research examines the contribution of attachment and motives to positive consumer response to event sponsors, in the form of sponsor image. This research then examines if sponsor image, in turn, influences the likelihood of purchasing sponsors' products, and repeat participation intent. The concept of sponsor image is reviewed next.

\section{Sponsor Image}

The concept of corporate, or company, image has been examined from a variety of marketing perspectives. Image can be defined as the sum of beliefs, attitudes, and impressions that a consumer or group of consumers holds for a company (Barich \& Kotler, 1991). An image of a sponsoring company exists in individuals' minds, and a single company does not have a universal corporate image (Brown \& Dacin, 1997). This is due, in part, to the fact that a company faces a variety of audiences (e.g., consumers, the media, employees). The current research focuses on the consumer audience, specifically, participants within a charity sport event sponsored by the company.

A greater emphasis has been placed on corporations evaluating and monitoring image to ensure that this element can be leveraged effectively. Individual perception of products and services are influenced by image, and image should serve a critical role within an organization's marketing communication (Dichter, 1985). Image can be used as a marketing tool to provide an organization with the opportunity to differentiate from competitors, enhance the perceived value of an organization's products and services, and attract and retain customers (Howard, 1998). Overall, research suggests that image can impact consumer product judgments and responses in a positive manner (Keller \& Aaker, 1992).

The concept of image is particularly relevant to sponsorship. Improvement of corporate image is a distinct objective of sponsorship, and sponsorship can have a positive, long-term impact on corporate image (Rajaretnam, 1994). Nonetheless, this effect can differ based on the company, as well as the type of sponsorship (Javalgi, Taylor, Gross, \& Lampman, 1994). Projecting a favorable image is relevant to the sport event sponsorship context, and identifying effective sport sponsorship opportunities is a challenge for corporations (e.g., Meenaghan \& Shipley, 1999; Wilber, 1988). Abratt, Clayton, and Pitt (1987) suggest that the sponsorship of sport can improve an organization's image through community involvement, building goodwill, and building or altering awareness. Meanwhile, Marshall and Cook (1992) identify enhancing 
corporate image as a factor driving corporations toward sport sponsorship.

Winters (1986) suggests that corporate image is influenced by three factors: business conduct, social conduct, and contributions. Social conduct reflects care about the public good, while contributions is based upon perceptions of a company's donations to charity. Both social conduct and contributions are relevant to the current research. Participatory sport events aligned with a charitable cause represent properties in which the community is brought together through physical activity in support of a designated charity. Sponsoring companies' respective images can be enhanced as a result of alignment with the event and these aspects.

For the purposes of this research, sponsor image is regarded as participants' favorable views of event sponsors as a result of their involvement with the event. Favorable views of event sponsors may be based upon factors such as the charitable component of the event, the event's role in the community, and the overall meaning participants hold for the event. While corporate image has been previously evaluated as multidimensional (Javalgi et al., 1994), this research focuses on perceptions based upon sponsorship, or sponsor image. Thus, a portion of overall corporate image is assessed (Johnson \& Zinkham, 1990).

The effects of sport sponsorship on corporate image and purchase intention have been researched previously (Stotlar, 1993). Pope and Voges (2000) revealed that sponsorship of sport has a direct relationship with both corporate image and intention to purchase the sponsoring company's products. The current research builds on the relationship between sport sponsorship and sponsor image by examining the relationships among motives, participant attachment, sponsor image, purchase intent toward event sponsors, and future participation. Through this examination, the following hypotheses are advanced:

Hypothesis 1: Recreation motives and charity motives will contribute to event attachment.

Hypothesis 2: Charity motives and event attachment will contribute to sponsor image within a sport event.

Hypothesis 3: Sponsor image and event attachment will contribute to the outcome of increased sponsor product purchase intent.

Hypothesis 4: Sponsor image and event attachment will contribute to the outcome of increased likelihood of future event participation intent. 


\section{Method}

\section{Participants}

A questionnaire was completed by a sample of participants $(\mathrm{N}=672)$ in the 2007 3M Half Marathon and Relay in Austin, Texas. This event, in its 13th year of existence, represents an established participatory sport event aligned with a charity, in which a portion of the event revenue benefits the Capital Area Food Bank of Texas. The event organization does not reveal the exact amount of revenue that is given to the selected charity to event participants. $3 \mathrm{M}$ is a technology company with a worldwide presence in markets such as consumer and office, health care, and safety services, and a multidivision U.S. headquarters in Austin, Texas. In addition to involvement with the Half Marathon and Relay promoting the city's active lifestyle, 3M has nonprofit partnerships in Austin with organizations including Big Brothers/Big Sisters, Literacy Austin, and Meals on Wheels.

Participants chose between a half marathon and a two-person half marathon relay. Individual participants were required to pay a \$40 registration fee in advance, or $\$ 80$ on race day, while relay team participants paid $\$ 80$ in advance, or $\$ 120$ on race day. The event attracted over 4,000 participants. The majority of participants registered via the internet (www.3mhalfmarathon.com), which provided additional exposure to, and information concerning, event sponsors. According to the event organizers, the audience for the 3M Half Marathon and Relay was predominantly white and affluent, between the ages of $25-50$, and comprised of $60 \%$ males and $40 \%$ females.

Respondents included 383 females and 289 males ranging in age from 18 to 65 with the majority (70\%) between the ages of 25-44. Thirty-seven percent had a monthly household income between US\$3,500 and US\$10,000, 70\% lived with a partner at home, 47\% had children, and $86 \%$ had obtained at least a Bachelor's degree. Ninety-eight percent of the sample had previously participated in the event, with $47 \%$ in their second year of participation.

\section{Materials}

Participants were given a multi-attribute questionnaire that included: (a) 12 items to measure Recreation Motives of Escape, Competency, Socialization, and Intellectual (Beard \& Ragheb, 1983); (b) 12 items to measure Charity Motives of Reciprocity, Self-Esteem, Need to Help Others, and Desire to Improve the Charity (Dawson, 1988; Gladden et al., 2004; Ritzenheim, 2000); (c) nine items to measure Event Attachment using Functional Knowledge, Emotional Importance, and Symbolic Expression (Funk \& James, 2006); and, (d) three items to measure Future Event Participation Intent. All items were measured on 7-point Likert scales (anchored by 1 = strongly disagree, 7 = strongly agree). To measure participants' perceptions of the image of 
sponsors (Sponsor Image), two Likert scale items using 7-point scales ( $1=$ not at all favorable, 7 = extremely favorable) were used to assess how sponsorship of the event caused participants to view $3 \mathrm{M}$ and how sponsorship of the event caused participants to view other sponsoring companies. To measure Sponsor Product Purchase Intent, two Likert items using 7-point scales (1 $=$ not at all likely, 7 = extremely likely) were used.

See the Appendix for a complete listing of the items used to assess Recreation Motives, Charity Motives, and Event Attachment. The Appendix also includes the items used to assess Sponsor Image, Sponsor Product Purchase Intent, and Future Event Participation Intent. The questionnaire also included a battery of demographic and behavioral questions such as number of hours spent training and number of previous events in which the respondent had participated.

\section{Procedures}

The questionnaire was administered online one week following the event. Participants were sent an e-mail with a link to the questionnaire. The e-mail was sent to 3,500 participants, with 672 usable questionnaires returned for a response rate of $19.2 \%$. The questionnaire was available to participants for two weeks following the initial e-mail.

\section{Analysis}

A two-step procedure was used to evaluate the relationship between the constructs of interest (Gerbing \&Anderson, 1988). The first stage examined the discrete nature and consistency of 40-items used to represent 14 constructs of Escape, Competency, Socialization, Intellectual, Reciprocity, Self-Esteem, Need to Help Others, Desire to Improve the Charity, Functional Knowledge, Emotional Importance, Symbolic Expression, Sponsor Image, Future Event Participation Intent, and Sport Product Purchase Intent. See variance extracted estimates, item loadings, and alpha coefficients reported in the Appendix.

The second stage employed factor score estimates to create nomological constructs of a) Recreation Motivation from Escape, Competency, Socialization, and Intellectual; b) Charity Motivation from Reciprocity, Self-Esteem, Need to Help Others, Desire to Improve the Charity; and c) Event Attachment from Functional Knowledge, Emotional Importance, and Symbolic Expression (See Table 1). The nomological approach allows for a macro examination of these constructs and their relationship to other key constructs through structural equation modeling (e.g., Iwasaki \& Havitz, 2004). The use of structural equation modeling to simultaneously test the relationships between the constructs offers "a more satisfactory approach to construct validation" (Diamantopoulos \& Winklhofer, 2001, p. 272). 


\section{Results}

\section{Measurement Details: Stage One}

A confirmatory factor analysis (CFA) was conducted using AMOS 4.1 (Arbuckle, 1994) to examine the psychometric properties of the constructs investigated in the study. The CFA is used to determine the construct validity of the conceptual variables to know how well those variables represent the underlying idea. Per Tabachnick and Fidell's (1996) recommendation, respondents with missing data points were deleted from the analysis. This procedure eliminated 13 subjects. A covariance matrix taken from the remaining respondents, employing maximum likelihood discrepancy, was used as the input data $(\mathrm{N}=672)$.

The CFA examined the relationships between the 40 observed variables and 14 first order latent variables Escape (ESC), Socialization (SOC), Competency (CPC), Intellectual (INL), Reciprocity (RPC), Self-Esteem (SES), Need to Help Others (NHO), Desire to Improve Charity (DIC), Functional Knowledge (FK), Emotional Importance (EI), Symbolic Expression (SE), Sponsor Image (SI), Future Event Participation Intent (FEPI), and Sponsor Product Purchase Intent (SPPI).All latent constructs were measured with 3-items with the exception of SI and SPPI which were measured with 2-items. See the Appendix.

Hu and Bentler's (1998) two-index combinational presentation strategy was used to examine the measurement model tested in the CFA. The two indices Root Mean Squared Error of Approximation (RMSEA) and Standardized Root Mean Squared Residual (SRMR) along with the recommended cut off values RMSEA $\$ .06)$ and SRMR $(\leq .06)$ were used to reduce the number of Type I and Type II error rates that occur in model specification regardless of sample size (Hu \& Bentler, 1999).

The analysis indicated the 40-items assessing the 14 constructs offer an acceptable fit to the data, $\chi 2=1885.85 / \mathrm{df}=649$; RMSEA $=.05 ;$ SRMR $=.05$ (Hu \& Bentler, 1999). Parameter estimates and accompanying $t$ tests corroborate significant connections between each scale item and its respective latent construct ( $\mathrm{p}<.01$ ). The items used to measure each of the 14 constructs revealed average variance extracted ranging from .49 (SES) to .90 (SPPI). Average variance extracted represents the average percentage of variation among the items representing a latent construct (Hair, Black, Babin, Anderson, \& Tatham, 2006), and it is recommended that at least $50 \%$ of the variance is explained (Bagozzi \& Yi, 1988). Internal consistency coefficients for each construct ranged from $\alpha=.74$ (SES) to $\alpha=.96$ (FEPI), which is within acceptable levels of internal consistency for applied research (Nunnally \&Bernstein,1994).A reliability coefficient represents the amount of measurement error present where a value of 1 is indicative of zero error 
(Hair et al., 2006). Refer to the Appendix for a complete listing of average variance extracted $(\mathrm{AVG})$ and internal consistency coefficients $(\alpha)$.

Inspection of the correlation matrix presented in Table 2 revealed moderate correlations between the 14 constructs and of the 92 potential relationships all were below $\mathrm{r}=.75$ (i.e., DIC-NHO). Two tests of discriminant validity were used to assess the discrete nature of the constructs. The first test employed Fornell and Larcker's (1981) test of discriminant validity and revealed that the average variance extracted by each of the items representing a construct exceeded the squared correlation between each construct. The second discriminant validity test examined the change in chi-square values resulting from fixing covariance between construct pairs to 1.0 (Burnkrant \& Page, 1982). Support was determined if changes in chi-square exceeded the baseline by $3.84(\mathrm{p}<.05)$ in the pairwise comparisons. The smallest chi-square difference observed was 16.50 , indicating strong support for discriminant validity between each construct (cf. Hightower, Brady, \& Baker, 2002).

\section{Measurement Details: Stage Two}

The second stage used summary estimates (i.e., factors scores) from each of the constructs to assess Recreation Motives, Charity Motives, and Event Attachment to develop a nomological measurement model (Gerbing \& Anderson, 1988). The structure used 18-indicators to reflect 6-latent constructs: (a) Recreation Motives with the four indicators: ESC, SOC, CPC, and INL; (b) Charity Motives with the four indicators: RPC, SES, NHO, and DIC; (c) Event Attachment with the three indicators: FK, EI, and SE; d) Sponsor Image with two indicators: SI1 and SI2; (e) Sponsor Product Purchase Intent with two indicators: SPPI1 and SPPI2; and (f) Future Event Participation Intent with three indicators: FEPI1, FEPI2, and FEPI3. Table 1 shows the results of the confirmatory factor analysis. Table 3 shows correlations, means, and standard deviations for the six constructs. See Figure 1 for a depiction of this model.

Confirmatory factor analysis using AMOS revealed an acceptable fit $\chi 2=434.18 / \mathrm{df}=120$; RMSEA = .06; SRMR = .05 (Hu \& Bentler, 1999). Parameter estimates and accompanying t tests substantiated connections between scale items and their respective constructs as significant $(\mathrm{p}<$ .01 ). The items used to measure each of the 11 constructs revealed average variance extracted ranging from $.43(\mathrm{RM})$ to .90 (SPPI), indicating one construct below the .50 benchmark (RM; Bagozzi \& Yi,

1988). Overall, internal consistency estimates for each construct were satisfactory, as they ranged from $\mathrm{a}=.74$ (RM) to $\alpha=.96$ (FEPI; Nunnally \& Bernstein, 1994). See Table 1 for average variance extracted and Table 3 for internal consistency estimates. Tests of discriminant validity (i.e., Burnkrant \& Page, 1982; Fornell \& Larcker, 1981) were conducted and indicated the 
discrete nature of each construct. These results provided support for the nomological measurement model to be employed to test a structural model developed from the hypotheses.

\section{Structural Test: Stage 2}

A structural test simultaneously examined the measurement model developed in Stage 2 and a structural model that tests the hypothesized relationships between the latent constructs (Diamantopoulos \& Winklhofer, 2001). Structural Equation Modeling (SEM) is a good statistical technique to examine complex and multidimensional variables because it allows complete and simultaneous tests of all relationships (Ullman, 2001). SEM can use both observed and unobserved (i.e., latent) variables to examine relationships hypothesized (Byrne, 1998). In addition, SEM can also isolate the error associated with each variable, and thus provide error free estimates of the relationships specified by the four hypotheses.

The structural test began with the specification of a model to create a statistical statement of relationships between latent variables RM, CM, EAT, SI, SPPI, and FEPI as determined by the hypotheses tendered. Model specification included the measurement model from Stage 2 and a structural model that specifies the relationships among the six latent variables. The objective of simple structural equation modeling was to examine how well linear relationships between these variables are represented in a meaningful and parsimonious way with the data from the 3M Half Marathon and Relay.

The structural model specified Recreation Motives and Charity Motives factors act as formative sources for Event Attachment. Charity Motives and Event Attachment act as formative sources for Sponsor Image. Sponsor Image and Event Attachment subsequently influence outcomes of Sponsor Product Purchase Intent and Future Event Participation Intent (See Figure $1)$.

AMOS 4.1 tested this sequence and noted an acceptable fit to the data $(\chi 2=448.91 / \mathrm{df}=127$, RMSEA $=.06$, SRMR = .05) (Hu \& Bentler, 1999). Additional fit measures were employed to examine the structure of relationships and yielded an acceptable fit $(\mathrm{GFI}=.93$, NFI $=.95$, TLI $=$ .95) (Browne \& Cudeck, 1993; Hair et al., 2006; Kline, 1998). Figure 1 provides the standardized regression weights for each of the model's proposed links. Results largely support the connections proposed in the hypotheses. Recreation Motives $(\beta=.55)$ and Charity Motives $(\beta=$ .21) explain $46 \%$ of the variance in the formation of Event Attachment. For Sponsor Image, Charity Motives $(\beta=.34)$ and Event Attachment $(\beta=.20)$ account for $21 \%$ of the variance. In terms of outcomes, Sponsor Image $(\beta=.61)$ and Event Attachment $(\beta=.19)$ explain $48 \%$ of the variance in Sponsor Product Purchase Intent. Event Attachment $(\beta=.50)$ alone explained $25 \%$ of the variance in Future Event Participation Intent. The Sponsor Image Future Event 
Participation Intent link was not supported $(\beta=-.01 \mathrm{p}=.89)$.

\section{Discussion}

Overall, the results introduce four main findings. First, recreation motives and charity motives contribute to event attachment. Second, charity motives and event attachment contribute to sponsor image. Third, sponsor image and event attachment contribute to sponsor product purchase intent. Fourth, event attachment contributes to future event participation intent while sponsor image does not. It should be noted that while the hypothesized measurement and structural model demonstrated an acceptable fit for these data, the structural equation modeling procedure does not establish causal relationships, but shows, "whether the causal assumptions embedded in the model match a sample of data” (Bollen, 1989, p. 4). An important next step is to validate the proposed model by fitting to other event data samples.

The contribution of recreation and charity motives in the development of attachment demonstrates motives related to leisure including escape, social, competency, and intellectual, along with motives related to charitable giving such as reciprocity, self-esteem, need to help others, and desire to improve the charity play a part in a sport event taking on enhanced importance and greater meaning for participants. This suggests individuals placed greater meaning on the event because it provided an opportunity to escape from their daily routine, socialize with others, and challenge themselves physically and intellectually. In addition, participants place greater meaning on the event because it provided an opportunity to support a charity from which they had benefited, enhanced their sense of self-worth, improved the lives and well-being of others, and pushed the charity toward success.

Also, the data revealed that recreation motives make a relatively stronger contribution to this meaning and importance than charity motives. Overall, this finding provides support for Hypothesis 1 . The recreation motives relate to the physical, social, and personal needs that can be satisfied by events (Getz, 1991). The contribution of both recreation and charity motives demonstrates that events can satisfy both core and contextual motives (Filo et al., 2008). Furthermore, this finding aligns with the notion that motives satisfied through event participation can take on enhanced meaning within the attachment process, leading to the event taking on emotional, symbolic, and functional meaning (Funk \& James, 2006).

The contribution of charity motives and event attachment to sponsor image suggests that motives related to charitable giving such as reciprocity, self-esteem, need to help others, and desire to improve the charity influence participants' favorable opinions of event sponsors. In addition, the emotional, symbolic, and functional meaning held for the event impacts perceptions 
of event sponsors. This suggests that participants were more likely to hold favorable opinions of event sponsors if s/he satisfied motives for charitable giving and ascribed emotional, symbolic and functional meaning to the event. Overall, this provides support for Hypothesis 2.

Notably, the stronger relative contribution of charity motives versus event attachment highlights the charitable component of the event in fostering opinions regarding image of the event sponsors. This supports the notion that sponsorship of sport can impact sponsor image through event-specific aspects such as community involvement and the building of goodwill (Abratt et al., 1987). In addition, the formative role event attachment has on sponsor image suggests the expression of connection to others (Wallendorf \& Arnould, 1988) can help build favorable public opinions for event sponsors. Furthermore, this provides evidence of attachment's role in the development of attitudes (Funk \& James, 2006), and connections (e.g., favorable opinions) with different aspects of a sport object (e.g., sport event sponsors) (Robinson \& Trail, 2005). This also supports the notion that favorable consumer response to a sport event transfers to event sponsors (Crimmins \& Horn, 1996).

The contribution of sponsor image and attachment to sponsor product purchase intent implies that both elements are important aspects for corporations to consider in the selection of event sponsorship opportunities. This contribution suggests that participants were more likely to indicate they would purchase sponsor products if they perceive favorable opinions of event sponsors, while ascribing emotional, symbolic, and functional meaning to the event. This finding provides support for Hypothesis 3. Sponsor image demonstrated a relatively stronger formative influence, while event attachment had both a direct impact as well as an indirect impact through its influence on sponsor image. Corporations can not only benefit from the favorable views generated through their event sponsorship, but can also benefit through alignment with events that hold greater meaning with participants.

The relationship between sponsor image and sponsor product purchase intent reveals that sponsor image may represent an effective mechanism for attracting and retaining customers (Howard, 1998). This demonstrates that sponsor image can have a positive influence on product judgments and responses among consumers (Keller \&Aaker, 1992). This finding provides additional evidence of the relationship among sport sponsorship, image, and intention to purchase sponsoring company's products (Pope \& Voges, 2000). The contribution of attachment to sponsor product purchase intent suggests that increased faithfulness to brands associated with the event could be an additional outcome of the event taking on emotional, symbolic, and functional meaning (Funk \& James, 2006).

Finally, sponsor image does not influence a participant's intention to participate in the event in the future, while event attachment does impact future participation intent. This suggests that a 
participant is more likely to indicate he/she will participate in the event in the future if they ascribe emotional, symbolic, and functional meaning to the event. Overall, these findings demonstrate partial support for Hypothesis 4, however the hypothesis is not fully supported as sponsor image does not influence future event participation intent. From an event management standpoint, sponsor image diminishes in importance in that it does not serve to retain participants, introducing implications for the marketing of sponsorship activities, and events overall. The contribution of attachment to future event participation intent reveals the event has taken on greater importance (Funk \& James, 2001, 2006) as reflected in participants' willingness and interest in repeat participation. Accordingly, event managers may want to emphasize and highlight the connection participants feel toward their event as a means to attract and retain participants.

\section{Theoretical Implications}

The findings introduce a number of theoretical implications. First, this research represents further refinement of attachment within the sport event context. The results reveal that recreation and charity motives satisfied through event participation (Filo et al., 2008) take on enhanced importance and contribute to the event taking on greater meaning (Funk \& James, 2006). Furthermore, the results highlight a stronger contribution from recreation motives, relative to charity motives in the development of event attachment in the sport event context.

Second, the findings advance factors that contribute to sponsor image in the sport event context. Charity motives including reciprocity, self-esteem, need to help others and desire to improve the charity, along with event attachment, lead to favorable opinions of event sponsors. The influence of charity motives aligns with the relevance of contributions, or a company's donations to charity, to an organization's image (Winters, 1986). However, additional variance could be explained that will further account for the diverse nature of sponsor image (Javalgi et al., 1994). The influence of event attachment on sponsor image corresponds with increased complexity of the sport event's associative network among participants and increased links to secondary aspects of the event, which underlie attachment (Funk \& James, 2001).

Finally, this research presents two behavioral intent outcomes resulting from event attachment: sponsor product purchase intent and future event participation intent. Event attachment influences future event participation intent, and to a lesser degree, sponsor product purchase intent. In the sport event context, these behavioral intentions could be viewed as characteristics of attached participants within the PCM framework. 


\section{Managerial Implications}

The findings of this research introduce a variety of implications for sport event managers. First, in the recruitment and solicitation of event sponsors and corporate partners, event managers can highlight the contribution of sponsor image to consumers' intention to purchase sponsors' products. Sport sponsorship and partnerships provide a corporation with benefits including media access and exposure, improved employee morale, and access to specific target markets (Slack \& Amis, 2001). The current research suggests that favorable perceptions of the sponsors' image, along with consumer purchase intent are additional benefits. Sponsor image appears to be an element of public goodwill that results from sponsorship (Levy, 2004), which can be communicated to event sponsors to bolster the attractiveness of the sponsorship opportunity.

Second, with attracting and retaining participants as a means to enhance event sustainability, event managers can emphasize event attachment. Sponsor image did not contribute to future event participation, and as a result it is not evident that participant perceptions of event sponsors influence individuals' decision to participate. Therefore, event managers should promote the meaning the event holds for participants, and the relationship participants share with the event, throughout all marketing communication to leverage event attachment toward increased participation. This resonates well with the findings of Chalip (1992), who argues for the more strategic use of multiple narratives, embedded genres, and layered symbols in the planning, design, and promotion of sport events.

Also, the contribution of charity motives to sponsor image highlights the relevance of the charitable component of the event to the overall sponsorship opportunity. To enhance the visibility and resonance of their image, sponsoring organizations can communicate the philanthropic aspect of their partnership. A ready made vehicle for doing so comes in the form of sponsors' incorporation of event imagery into their advertising. While Chalip (2004) argues this can render longer-term benefits to event hosts in terms of the exposure provided the event and host region, O’Brien and Chalip (2008) suggest such tactics can also be used to target social change outcomes in host communities. Clearly, in light of the findings of the current research, it would appear that sponsors' alignment with the charitable components of sport events, and their strategic use of this alignment in advertising and promotions, has the potential to deliver benefits to multiple stakeholders.

Finally, the finding that sponsor image does not influence future event participation intent has implications for both event managers and sponsors. Day (2000) describes the importance of business partners understanding the needs and goals of one another, and highlights a focus on mutual benefits among collaborative partnerships. Future event participation intent represents a mutual benefit of sponsorship in that it results in additional, repeat exposure for the sponsoring 
organization along with participant retention for the event organization. Event sponsors can look to determine how they can assist event managers in achieving future event participation. Collaboration between event sponsors and managers would introduce relationship marketing to the partnership to assist in achieving competitive advantage and mutually desired outcomes (Cousens, Babiak, \& Bradish, 2006).

\section{Limitations}

Limitations of the current research should be recognized. First, the items used to assess Sponsor Image and Sponsor Product Purchase Intent had not been previously tested. Future work is needed to expand and further refine these scales. Second, due to logistical issues such as individuals registering without providing an e-mail address, or individuals providing an incorrect e-mail address; the link to the online questionnaire was administered to 3,500 participants. The event attracted an audience of over 4,000 participants leaving a little more than 500 individuals out of the sample overall. In addition, the sample comprised of 57\% females, while the event drew an audience comprised of $60 \%$ males. Thus, difference in the gender make up for the sample versus the event audience is acknowledged.

Furthermore, an additional delineation among sponsorship levels was not provided. The items used to assess Sponsor Image addressed the title sponsor and “a sponsoring company,” without attempting to differentiate among the event's sponsors, and it is likely that the inputs and outcomes vary across sponsors based on exposure. Finally, the use of online administration is a limitation in that select individuals may not have been able to complete the questionnaire in the allotted time due to lack of familiarity with, or accessibility to, the Internet. Online administration was nonetheless deemed suitable for the current research as the event's participant base reflects a young, Internet-savvy segment, as well as the fact that registration for the event was conducted online.

\section{Future Directions}

Using the findings of this research as a starting point, a number of future studies can be conducted. To validate the model advanced by this research, additional samples of data across a variety of sport event contexts could be used to fit the model.

Second, qualitative data could be collected at the event exploring participants' views of event sponsors and their relationship with the event. With the expectation that event experiences would vary across participants, semi-structured interviews could be conducted with participants (Veal, 2006) to better understand the meaning the event and sponsors hold in participants' lives. 
Furthermore, participant awareness of the sponsors could be examined, along with spectator perceptions and awareness of the sponsors.

The current research assessed sponsorship outcomes (i.e., SPPI) in terms of behavioral intent, rather than a more tangible behavioral outcome (i.e., dollars spent). Future research could allow for cost-benefit calculation, as well as estimation of return on investment for sponsors, through the examination of dollars spent by event participants and revenue generated immediately following the sponsorship. This would allow sponsors to assess the influence of sponsor image within sponsorship in more material terms.

Next, data can be collected from event sponsors examining their strategies for selecting sponsorship opportunities, as well as the outcomes sought through event sponsorship. This research could provide insight into organizations' attitudes toward shaping image via sport sponsorship, as well as their views on collaboration and mutually derived benefits through sport event sponsorship (Cousens et al., 2006). Furthermore, the event examined in the current research did include a benefiting charity, however, only a portion of event proceeds went to this charity, and the charitable cause did not figure prominently throughout event marketing communication. Future work can examine events with a more focal charitable component to determine if the overall meaning the event holds, as well as the favorable perceptions of event sponsors, are more pronounced among participants.

Finally, delineation was not made regarding the aspect of the event, or sponsors' involvement in the event, which made the strongest relative contribution to participant perceptions of event sponsors. Participants may have viewed involvement in an event advocating an active and healthy lifestyle as most favorable, while others may have felt the alignment with the charity was more favorable. Future research can look to specify, and perhaps compare, the different facets of charity sport events that shape participant perceptions of event sponsors.

\section{Conclusion}

This research uncovers the factors that contribute to event attachment and sponsor image for event sponsors, along with the influence of these two factors on sponsor product purchase intent and future event participation intent. Recreation motives and charity motives contribute to event attachment, while charity motives and event attachment contribute to sponsor image. In addition, both sponsor image and attachment influence participants' intent to purchase event sponsors' product, while attachment influences individuals' intent to participate in the event in the future. It is hoped that this research leads to further exploration of perceptions of sponsor image in the charity sport event context to assist corporations in developing strategies for the selection and 
optimization of sport event sponsorship opportunities. Furthermore, additional work can be done on the different aspects of the event that contribute to sponsor image. This can assist event managers in developing successful strategies for attracting event sponsors.

\section{Acknowledgment}

The authors wish to acknowledge the support provided by the Centre for Tourism, Sport and Service Innovation at Griffith University 


\section{References}

Abratt, R., Clayton, B.C., \& Pitt, L.F. (1987). Corporate objectives in sports sponsorship. International Journal of Advertising, 6, 299-311.

Amos, O.M. (1982). Empirical analysis of motives underlying individual contributions to charity. Atlantic Economic Journal, 10(4), 45-52.

Arbuckle, J.L. (1994). AMOS: Analysis of moment structures. Psychometrika, 59, 135-137.

Bagozzi, R.P., \& Yi, Y. (1988). On the evaluation of structural equation models. Journal of the Academy of Marketing Science, 16, 74-94.

Barich, H., \& Kotler, P. (1991). A framework for marketing image management. Sloan Management Review, 32, 94-104.

Beard, J.G., \& Ragheb, M.G. (1983). Measuring leisure motivation. Journal of Leisure Research, 15, 219-228.

Beaton, A.A., \& Funk, D.C. (2008). An evaluation of theoretical frameworks for studying physically active leisure. Leisure Sciences, 30, 53-70.

Bollen, K.A. (1989). Structural equations with latent variables. New York: Wiley.

Brown, T.J., \& Dacin, P.A. (1997). The company and the product: Corporate associations and consumer product responses. Journal of Marketing, 61(1), 68-84.

Browne, M.W., \& Cudeck, R. (1993).Alternative ways of assessing model fit. In K.A. Bollen \& J.S. Long (Eds.), Testing structural equation models (pp. 136-163). Newbury Park: Sage Publications.

Burnkrant, R.E., \& Page, T.J. (1982). An examination of the convergent, discriminant, and predictive validity of Fishbein's behavioral intention model. JMR, Journal of Marketing Research, 19, $550-561$.

Byrne, B.M. (1998). Structural equation modeling with LISREL, PRELIS, and SIMPLIS: Basic concepts, applications, and programming. Mahwah, NJ: Lawrence Erlbaum Associates.

Cause Marketing Forum. (2008). The Growth of Cause Marketing. Retrieved July 7, 2008, from http://www.causemarketingforum.com/page.asp?ID=188

Chalip, L. (1992). The construction and use of polysemic structures: Olympic lessons for sport marketing. Journal of Sport Management, 6, 87-98.

Chalip, L. (2004). Beyond impact: A general model for sport event leverage. In B.W. Ritchie \& D.Adair (Eds.), Sport tourism: Interrelationships, impacts, and issues (pp. 226-252). Clevedon, UK: Channel View Publications.

Cousens, L., Babiak, K., \& Bradish, C.L. (2006). Beyond sponsorship: Re-framing corporate-sport relationships. Sport Management Review, 9, 1-23.

Crimmins, J., \& Horn, M. (1996). Sponsorship: From management ego trip to marketing success. Journal of Advertising Research, 36(4), 11-21. 
Crompton, J.L. (1979). Motivations for pleasure vacation. Annals of Tourism Research, 24, 408-424.

Crompton, J.L., \& McKay, S.L. (1997). Motives of visitors attending festival events. Annals of Tourism Research, 24, 425-439.

Dawson, S. (1988). Four Motivations for Charitable Giving: Implications for marketing strategy to attract monetary donations for medical research. Journal of Health Care Marketing, 8(2), 31-37.

Day, G.S. (2000). Managing market relationships. Journal of the Academy of Marketing Science, 28, 24-30.

Diamantopoulos,A., \&Winklhofer, H.M. (2001). Index construction with formative indicators: An alternative to scale development. JMR, Journal of Marketing Research, 38, 269-277.

Dichter, E. (1985). What's in an image. Journal of Consumer Marketing, 2, 75-81.

Ebenkamp, B., \& Stark, M. (1999). Brand aid: Cause effective. Brandweek, 40(8), 20-22.

Filo, K., Funk, D.C., \& O’Brien, D. (2008). It's really not about the bike: Exploring attraction and attachment to the events of the Lance Armstrong Foundation. Journal of Sport Management, 22, 501-525.

Filo, K., Funk, D.C., \& O’Brien, D. (2009). The meaning behind attachment: Exploring camaraderie, cause, and competency at a charity sport event. Journal of Sport Management, 23, 361-387.

Fisher, R.J., \& Wakefield, K. (1998). Factors leading to group identification: A field study of winners and losers. Psychology and Marketing, 15, 23-40.

Frederick, C.M., \& Ryan, R.M. (1993). Differences in motivation for sport and exercise and their relations with participation and mental health. Journal of Sport Behavior, 16, 124-146.

Fornell, C., \& Larcker, D.F. (1981). Evaluating structural equation models with unobservable variables and measurement error. JMR, Journal of Marketing Research, 18, 39-50.

Funk, D.C., \& James, J. (2001). The psychological continuum model: A conceptual framework for understanding an individual's psychological connection to sport. Sport Management Review, 4, 119-150.

Funk, D.C., \& James, J. (2004). The fan attitude network (FAN) model: Exploring attitude formation and change among sport consumers. Sport Management Review, 7, 1-26.

Funk, D.C., \& James, J. (2006). Consumer loyalty: The meaning of attachment in the development of sport team allegiance. Journal of Sport Management, 20, 189-217.

Funk, D.C., Toohey, K., \& Bruun, T. (2007). International sport event participation: Prior sport involvement; destination image; and travel motives. European Sport Management Quarterly, 7, 227-248.

Gerbing, D.W., \&Anderson, J.C. (1988). An updated paradigm for scale development incorporating unidimensionality and its assessment. JMR, Journal of Marketing Research, 25, 186-192.

Getz, D. (1991). Festivals, special events, and tourism. New York: Von Nostriand Reinhold.

Gladden, J.M., Mahony, D.F., \& Apostolopoulou, A. (2004). Toward a better understanding of college athletic donors: What are the primary motives? Sport Marketing Quarterly, 13, 194-208. 
Gwinner, K.P., \& Eaton, J. (1999). Building brand image through event sponsorship: The role of image transfer. Journal of Advertising, 28(4), 47-57.

Hair, J.F., Black, W.C., Babin, B.J., Anderson, R.E., \& Tatham, R.L. (2006). Multivariate analysis (6th ed.). Upper Saddle River, NJ: Pearson.

Hibbert, S., \& Horne, S. (1996). Giving to charity: Questioning the donor process. Journal of Consumer Marketing, 13(2), 4-13.

Hightower, R., Brady, M. K., \& Baker, T. L. (2002). Investigating the role of physical environment in hedonic service consumption: an exploratory study of sporting events. Journal of Business Research, 55, 697-707.

Howard, S. (1998). Corporate Image Management. Singapore: Reed Academic Publishing.

Hu, L., \& Bentler, P.M. (1999). Cutoff criteria for fit indexes in covariance structure analysis: conventional criteria versus new alternatives. Structural Equation Modeling, 6, 1-56.

Iso-Ahola, S.E. (1980). The social psychology of leisure and recreation. Dubuque, IA: Wm. C. Brown.

Iso-Ahola, S.E. (1982). Toward a social psychological theory of tourism motivation: A rejoinder. Annals of Tourism Research, 9, 256-262.

Iwasaki, Y., \& Havitz, M.E. (1998). A path analytic model of the relationships between involvement, psychological commitment, and loyalty. Journal of Leisure Research, 30, 256-280.

Javalgi, R.G., Traylor, M.B., Gross, A.C., \& Lampman, E. (1994). Awareness of sponsorship and corporate image: An empirical investigation. Journal of Advertising, 23(4), 47-58.

Johnson, M., \& Zinkham, G.M. (1990). Defining and measuring company image. In B. J. Dunlap (Ed.) Proceedings from the $13^{\text {th }}$ Annual Academy of Marketing Science (pp. 346-350), Cullowhee, NC (Academy of Marketing Science: Developments in Marketing Science).

Kavussanu, M., \& Roberts, G.C. (1996). Motivation in physical activity contexts: The relationship of perceived motivational climate to intrinsic motivation and self-efficacy. Journal of Sport and Exercise Physiology, 18, 264-280.

Keller, K.L., \& Aaker, D.A. (1992). The effects of sequential introduction of brand extensions. JMR, Journal of Marketing Research, 29, 35-50.

Kilpatrick, M., Hebert, E., \& Bartholomew, J. (2005). College students' motivation for physical activity: Differentiating men's and women's motives for sport participation and exercise. Journal of American College Health, 54(2), 87-94.

King, S. (2001). Breast cancer, corporate philanthropy, and the market for generosity. Social Text 69, 19(4), 115-143.

Kline, R.B. (1998). Principles and practice of structural equation modeling. New York: Guilford Press.

Koivula, N. (1999). Sport participation: Differences in motivation and actual participation due to gender typing. Journal of Sport Behavior, 22, 360-379.

Kottasz, R. (2004). How should charitable organisations motivate young professionals to give 
philanthropically? International Journal of Nonprofit and Voluntary Sector Marketing, 9, 9-27. Laverie, D.A. (1998). Motivations for ongoing participation in a fitness activity. Leisure Sciences, 20, 277-302.

Levy, R. (2004). Sponsorship: What's in it for you? Public Relations Quarterly, 49(3), 42-43.

Mannell, R.C., \& Iso-Ahola, S.E. (1987). Psychological nature of leisure and tourism experience. Annals of Tourism Research, 14, 314-331.

Marshall, D.W., \& Cook, G. (1992). The corporate (sports) sponsor. International Journal of Advertising, 11, 307-324.

Marx, J.D. (2000). Women and human services giving. Social Work, 45, 27-38.

Maslow, A. (1954). Motivation and personality. New York: Harper and Row.

Meenaghan, T., \& Shipley, D. (1999). Media effect in commercial sponsorship. European Journal of Marketing, 33, 328-348.

National Center for Charitable Statistics. (2004). Number of Nonprofit Organizations in the United States 1996-2004. Retrieved January 31, 2006, from http://nccsdataweb.urban. org/PubApps/profile1.php?state=US

National Center for Charitable Statistics. (2007). Number of Nonprofit Organizations in the United States 1996-2006. Retrieved July 7, 2008, from http://nccsdataweb.urban.org/ PubApps/profile1.php?state=US

Nunnally, J.C., \& Bernstein, I.H. (1994). Psychometric theory (3rd ed.). NewYork: McGraw-Hill.

O’Brien, D., \& Chalip, L. (2008). Sport events and strategic leveraging: Pushing towards the triple bottom line. InA. Woodside \& D. Martin (Eds.), Advancing Tourism Management (pp. 318-338). Cambridge, MA: CABI Publishing.

Pope, N.K.L., \& Voges, K.E. (2000). The impact of sport sponsorship activities, corporate image, and prior use on consumer purchase intention. Sport Marketing Quarterly, 9, 96-102.

Rajaretnam, J. (1994). The long-term effects of sponsorship on corporate and product image: Findings of a unique experiment. Marketing and Research Today, 22, 62-74.

Ritzenheim, D.N. (2000). One more time: How do you motivate donors? New Directions for Philanthropic Fundraising, 29, 51-68.

Robinson, M.J., \& Trail, G.J. (2005). Relationships among spectator, gender, motives, points of attachment, and sport preference. Journal of Sport Management, 19, 58-80.

Schultz, S.E., Kleine, R.E., \& Kernan, J.B. (1989). “These are a few of my favorite things” Toward an explication of attachment as a consumer behavior construct. Advances in Consumer Research. Association for Consumer Research (U. S.), 16, 359-366.

Slack, T., \& Amis, J. (2001). Sport sponsorship. In D. Pickton \& A. Broderick (Eds.), Integrated Marketing Communications (pp. 510-530). London: Financial Times-Prentice Hall.

Staurowsky, E.J., Parkhouse, B., \& Sachs, M. (1996). Developing an instrument to measure athletic donor behavior and motivation. Journal of Sport Management, 10, 262-277. 
Stewart, B., Smith, A.C.T., \& Nicholson, M. (2003). Sport consumer typologies: A critical review. Sport Marketing Quarterly, 4, 206-216.

Stinson, J.L., \& Howard, D.R. (2004). Scoreboards vs. mortarboards: Major donor behavior and intercollegiate athletics. Sport Marketing Quarterly, 13, 129-140.

Stinson, J.L., \& Howard, D.R. (2007). Athletic success and private giving to athletic and academic programs at NCAA institutions. Journal of Sport Management, 21, 235-264.

Stinson, J.L., \& Howard, D.R. (2008). Winning does matter: Patterns in private giving to athletic and academic programs at NCAA Division I-AA and I-AAA institutions. Sport Management Review, $11,1-20$.

Stotlar, D.K. (1993). Sponsorship and the Olympic Winter Games. Sport Marketing Quarterly, 2, 35-43.

Tabachnick, B.G., \& Fidell, L.S. (1996). Using multivariate statistics (3rd ed.). New York: Harper Collins.

Trail, G.T., Anderson, D.F., \& Fink, J.S. (2000). A theoretical model of sport spectator consumption behavior. International Journal of Sport Management, 1, 154-180.

Ullman, J.B. (2001). Structural equation modeling. In B.G. Tabachnik \& L.S. Fidell (Eds.), Using multivariate statistics (pp. 653-771). Boston: Allyn and Bacon.

U.S. Census Bureau. (2007). Sports participation in 2005: Series 1 and series II. Retrieved July 7, 2008, from http://www.census.gov/compendia/statab/tables/08s1222.xls Veal, A.J. (2006).

Research methods for leisure and tourism: A practical guide. Sydney: Pearson Education.

Wallendorf, M., \& Arnould, E.J. (1988). "My favorite things”: A cross-cultural inquiry into object attachment, possessiveness, and social linkage. The Journal of Consumer Research, 14, 531-547. Wilber, D. (1988). Linking sports and sponsors. The Journal of Business Strategy, 9(4), 8-10. Winters, L.C. (1986). The effect of brand advertising on company image: Implications for corporate advertising. Journal of Advertising Research, 26, 54-59. Zhang, Q.H., \& Lam, T. (1999). An analysis of mainland Chinese visitors' motivations to visit Hong Kong. Tourism Management, 20, 587-594. 
Table 1 Measurement Results for Recreation Motives, Charity Motives, Event Attachment, Sponsor Image, Sponsor Product Purchase Intent, and Future Event Participation Intent $(N=672)$

\begin{tabular}{|c|c|c|c|}
\hline Constructs & $\begin{array}{c}\text { Mean } \\
(S D)\end{array}$ & $\beta$ & Avg \\
\hline Recreation Motives (RM) & & & .43 \\
\hline Social (SOC) & $3.94(1.48)$ & .76 & \\
\hline Escape (ESC) & $4.67(1.49)$ & .62 & \\
\hline Competency (CPC) & $6.23(0.86)$ & .47 & \\
\hline Intellectual (INL) & $3.92(1.66)$ & .73 & \\
\hline Charity Motives (CM) & & & .56 \\
\hline Reciprocity (RPC) & $2.17(1.32)$ & .36 & \\
\hline Self-Esteem (SES) & $3.87(1.24)$ & .80 & \\
\hline Need to Help Others (NHO) & $4.00(1.52)$ & .87 & \\
\hline Desire to Improve Charity (DIC) & $4.50(1.38)$ & .85 & \\
\hline Event Attachment (EAT) & & & .55 \\
\hline Functional & $3.40(1.49)$ & .62 & \\
\hline Emotional & $4.20(1.58)$ & .92 & \\
\hline Symbolic & $4.30(1.56)$ & .64 & \\
\hline Sponsor Image (SI) & & & .85 \\
\hline $\begin{array}{l}\text { SI1—How favorably does sponsorship of this } \\
\text { event cause you to view 3M? }\end{array}$ & $5.29(1.47)$ & .92 & \\
\hline $\begin{array}{l}\text { SI2-How favorably does sponsorship of this } \\
\text { event cause you to view a sponsoring company? }\end{array}$ & $5.29(1.41)$ & .93 & \\
\hline Future Event Participation Intent (FEPI) & & & .89 \\
\hline $\begin{array}{l}\text { FEPI 1-It is highly likely that I will participate } \\
\text { in the } 2008 \text { 3M Half Marathon \& Relay }\end{array}$ & $5.77(1.48)$ & .86 & \\
\hline $\begin{array}{l}\text { FEPI 2-The probability is high that I will par } \\
\text { ticipate in the } 2008 \text { 3M Half Marathon \& Relay }\end{array}$ & $5.93(1.43)$ & .99 & \\
\hline $\begin{array}{l}\text { FEPI 3-The likelihood of me participating in } \\
\text { the } 2008 \text { 3M Half Marathon \& Relay is very }\end{array}$ & $5.84(1.50)$ & .97 & \\
\hline \multicolumn{4}{|l|}{ high } \\
\hline Sponsor Product Purchase Intent (SPPI) & & & .90 \\
\hline $\begin{array}{l}\text { SPPI } 1 \text { - How likely are you to purchase } 3 \mathrm{M} \\
\text { products as a result of the race? }\end{array}$ & $4.61(1.60)$ & .92 & \\
\hline $\begin{array}{l}\text { SPPI 2-How likely does sponsorship of this } \\
\text { event influence you to use or purchase }\end{array}$ & $4.15(1.59)$ & .97 & \\
\hline a sponsoring company's products? & & & \\
\hline
\end{tabular}

Notes. $\beta=$ standardized regression coefficients for manifest variables. AVG: average variance extracted by manifest variables for each construct. 


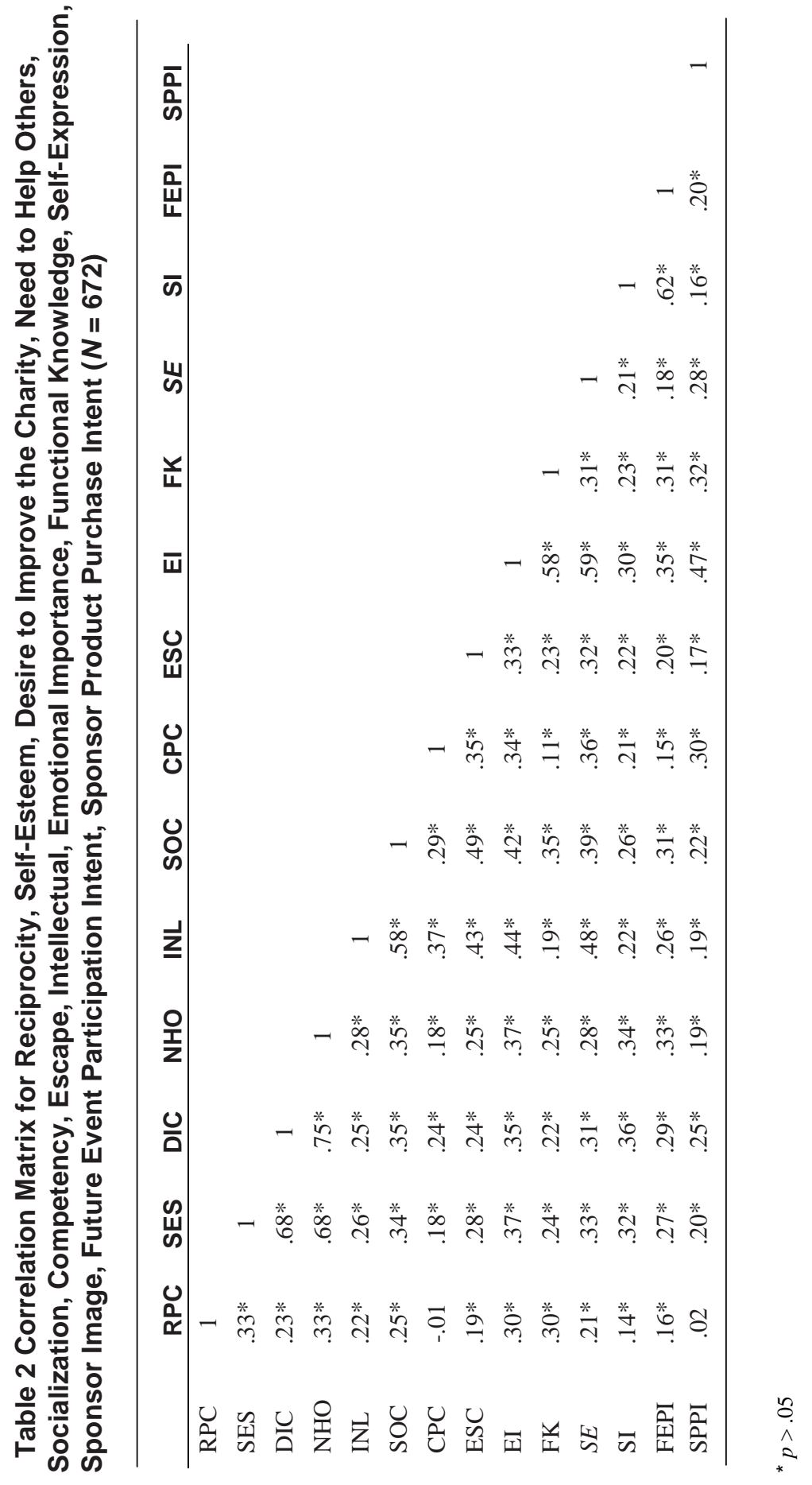


Table 3 Correlation Matrix for Recreation Motives, Charity Motives, Event Attachment, Sponsor Image, Sponsor Product Purchase Intent, and Future Event Participation Intent $(N=672)$

\begin{tabular}{lccccccccc}
\hline & RM & CM & EAT & SI & SPPI & FEPI & M & SD & $\alpha$ \\
\hline RM & 1 & & & & & & 4.70 & 1.05 & .74 \\
CM & $.41^{*}$ & 1 & & & & & 3.64 & 1.08 & .80 \\
EAT & $.54 *$ & $.46^{*}$ & 1 & & & & 3.96 & 1.25 & .75 \\
SI & $.30 *$ & $.37 *$ & $.30 *$ & 1 & & & 5.29 & 1.39 & .92 \\
SPPI & $.32 *$ & $.34^{*}$ & $.34 *$ & $.62^{*}$ & 1 & & 4.56 & 1.56 & .95 \\
FEPI & $.27 *$ & $.21 *$ & $.44^{*}$ & $.16^{*}$ & $.20 *$ & 1 & 5.84 & 1.41 & .96 \\
\hline
\end{tabular}

${ }^{\star} p>.05$

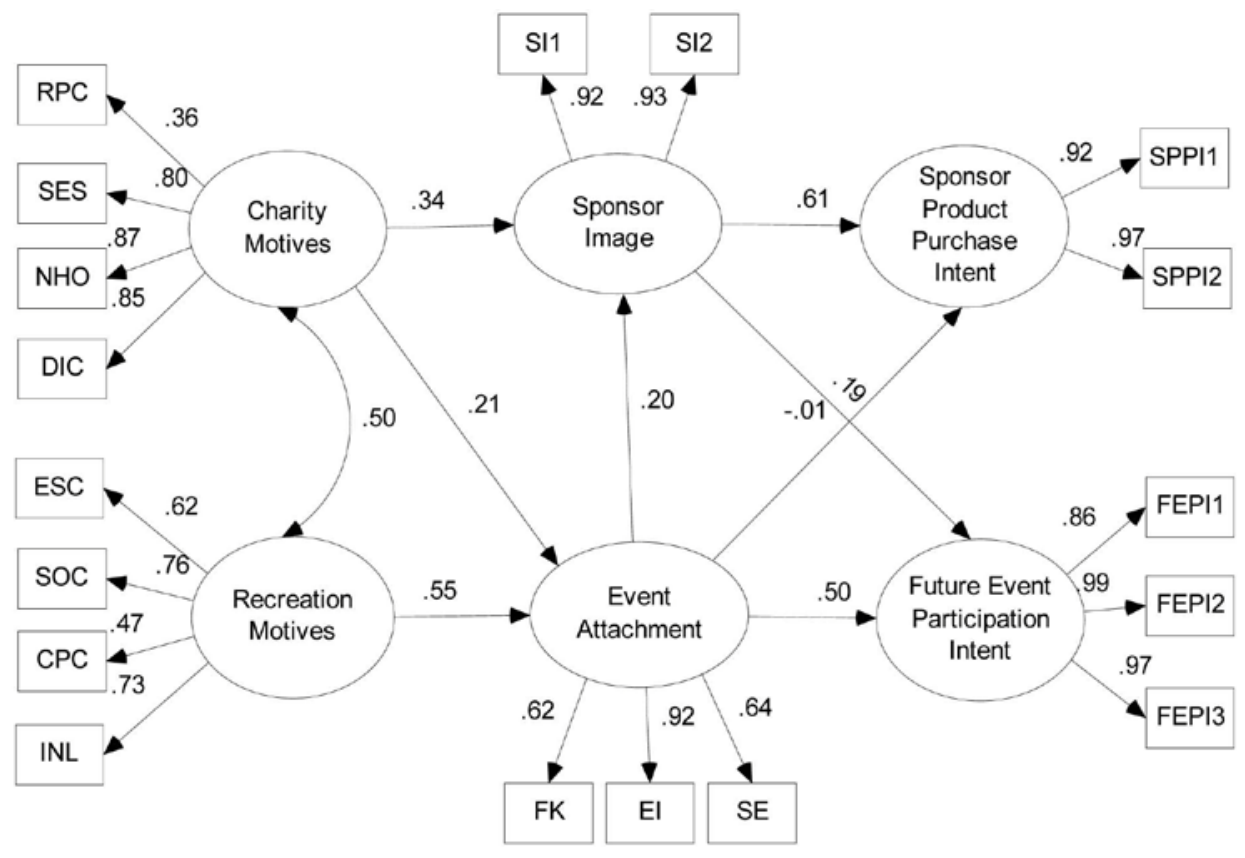

$p<.05$

Figure 1 - Structural test for formative sources of sponsor image, attachment, and outcomes. 


\section{Appendix}

\section{Multi-Attribute Scales to Measure Recreation Motives, Charitable Giving Motives, and Event Attachment $(N=672)$}

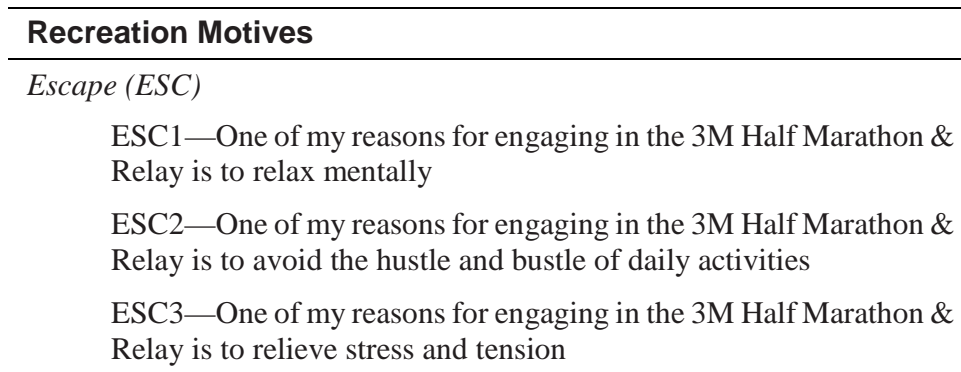

Socialization (SOC)

$\begin{array}{cc}\alpha / \beta & \text { AVG } \\ \alpha=.83 & .63\end{array}$

.76

.77

.85

$\alpha=.86$

SOC1—One of my reasons for engaging in the 3M Half Marathon \& Relay is to interact with others

SOC2-One of my reasons for engaging in the 3M Half Marathon \& Relay is to meet new and different people

SOC3-One of my reasons for engaging in the 3M Half Marathon \& Relay is to gain a feeling of belonging

Competency (CPC)

$\alpha=.83$

COM1-One of my reasons for engaging in the 3M Half Marathon

\& Relay is to challenge my abilities

.87

COM2-One of my reasons for engaging in the 3M Half Marathon \& Relay is to improve my skill and ability in doing the activity

COM3-One of my reasons for engaging in the 3M Half Marathon \& Relay is to keep in shape physically

Intellectual (INL)

$\alpha=.90$

INL1-One of my reasons for engaging in the 3M Half Marathon \& Relay is to learn about myself

INL2-One of my reasons for engaging in the 3M Half Marathon \& Relay is to expand my knowledge

INL3 - One of my reasons for engaging in the 3M Half Marathon \& Relay is to discover new things

\begin{tabular}{l}
\hline Charity Motives \\
\hline Reciprocity (RPC) \\
RPC1—The activities of the Capital Area Food Bank of Texas have \\
improved the quality of life of people who are close to me \\
RPC2—I feel indebted to the Capital Area Food Bank of Texas for \\
helping my family and friends in the past \\
RPC3-The Capital Area Food Bank of Texas has been responsible \\
for improving the quality of life of people close to me
\end{tabular}

$\alpha / \beta$

AVG

$\alpha=.89$

.77

.73

(continued) 
Appendix (continued)

\begin{tabular}{l} 
Charity Motives (continued) \\
\hline Self-Esteem (SES) \\
SES1_-Other people will think more highly of me if I donate time \\
or money to the Capital Area Food Bank of Texas \\
SES2_-I have a good feeling after making a gift to the Capital Are \\
Food Bank of Texas \\
SES3 - People who are most respected by society are those who \\
give to charitable organizations
\end{tabular}

Need to Help Other (NHO)

$\begin{array}{cc}\alpha / \beta & \text { AVG } \\ \alpha=.74 & .49\end{array}$

.60

$\alpha=.88$

NHO1-Giving to the Capital Area Food Bank of Texas provides my life with greater purpose

NHO2-I give to the Capital Area Food Bank of Texas because their goals are consistent with my values

NHO3 - I give to the Capital Area Food Bank of Texas because I feel a need to help others

Desire to Improve Charity (DIC)

$\alpha=.83$

DIC1-Giving to the Capital Area Food Bank of Texas allows me to support a quality charity

DIC2-Giving to the Capital Area Food Bank of Texas allows me to enhance the prestige of the charity

DIC3-Giving to the Capital Area Food Bank of Texas allows me to push the organization toward success

\begin{tabular}{|c|c|c|}
\hline Event Attachment & $\alpha / \beta$ & AVG \\
\hline Functional Knowledge (FK) & $\alpha=.92$ & .79 \\
\hline $\begin{array}{l}\text { FK1-I possess a great deal of knowledge about the 3M Half } \\
\text { Marathon \& Relay }\end{array}$ & .82 & \\
\hline $\begin{array}{l}\text { FK2-Compared with other events, I consider myself an expert on } \\
\text { the 3M Half Marathon \& Relay }\end{array}$ & .94 & \\
\hline $\begin{array}{l}\text { FK3-If I were to list everything I know about the 3M Half } \\
\text { Marathon \& Relay, the list would be quite long }\end{array}$ & .92 & \\
\hline Emotional Importance (EI) & $\alpha=.95$ & .86 \\
\hline EI1-The 3M Half Marathon \& Relay is important to me & .93 & \\
\hline $\begin{array}{l}\text { EI2_Being a participant in the } 3 \mathrm{M} \text { Half Marathon \& Relay is very } \\
\text { important to me }\end{array}$ & .96 & \\
\hline $\begin{array}{l}\text { EI3-Compared with other events, the } 3 \mathrm{M} \text { Half Marathon \& Relay } \\
\text { is very important to me }\end{array}$ & .89 & \\
\hline Symbolic Expression (SE) & $\alpha=.92$ & .80 \\
\hline $\begin{array}{l}\text { SE1-Participating in the } 3 \mathrm{M} \text { Half Marathon \& Relay says a lot } \\
\text { about who I am }\end{array}$ & .80 & \\
\hline
\end{tabular}


SE2-Participating in the 3M Half Marathon \& Relay gives a glimpse of the type of person I am

SE3-Participating in the 3M Half Marathon \& Relay tells something about me

Sponsor Image (SI)

$\alpha=.92$

SI1—How favorably does sponsorship of this event cause you to view $3 \mathrm{M}$ ?

SI2-How favorably does sponsorship of this event cause you to view a sponsoring company?

\section{$5.29(1.41) \quad .93$}

$\alpha=.96$

FEPI 1-It is highly likely that I will participate in the 2008 3M Half Marathon \& Relay

FEPI 2-The probability is high that I will participate in the 2008 3M Half Marathon \& Relay

FEPI 3-The likelihood of me participating in the 2008 3M Half Marathon \& Relay is very high

SPPI 1 - How likely are you to purchase $3 \mathrm{M}$ products as a result of the race?

SPPI 2-How likely does sponsorship of this event influence you to use or purchase a sponsoring company's products? 